\title{
DOES EUROPEAN AID WORK? \\ AN ETHIOPIAN CASE STUDY
}

\author{
Simon Maxwell ${ }^{1}$
}

IDS Working Paper 46

\begin{abstract}
Summary
European aid is a business whose future is hotly debated. 'Maximalists' would like to see growth in community action at the expense of national action, with deepening and possible geographical widening of Lomé relationships, accompanied by greater political accountability. 'Minimalists' would abandon the idea of contractuality and partnership with Lomé countries, and renationalise aid wherever possible. In adjudicating between these competing visions, issues of aid quality are central, taking quality to mean not just the long term development impact of aid, but also its effectiveness in meeting short term objectives, and its implementation efficiency. An evaluation of EU aid to Ethiopia, valued at close to \$US 2.5 billion dollars over eighteen years, throws light on the issue of aid quality. Some aid, perhaps most, 'worked'; but some did not - for reasons partly internal to Ethiopia and partly internal to the EU. The EU programme has improved markedly but could improve further: a seven point action programme is proposed to enable the EU to achieve an objectivedriven strategy. A shift of resources from national action to community action would then be justified, capitalising on the economies of scale and the scope for more effective policy dialogue. A European Development Agency would also become an attractive idea.
\end{abstract}

\footnotetext{
1. Simon Maxwell is a Fellow of the Institute of Development Studies at the University of Sussex, and Programme Manager for Rural Poverty, Food Security and the Environment.
} 


\section{Introduction ${ }^{2}$}

The European Union is never short on controversy; and in the sphere of development aid, a business now worth $\$$ US 5 billion a year to the $\mathrm{EU}^{3}$, there is certainly much to discuss at present. In 1995, the mid-term review of Lomé IV was completed and an acrimonious dispute was settled about the level of funding available to the year 2000: in neither case was the outcome particularly favourable to developing countries ${ }^{4}$. In 1996, attention has turned to the future of development aid after that time, when Lomé IV expires. Here, a Green Paper has been published by the Commission (EC 1996) and there is a many-layered debate. The debate ranges from the high politics of first world-third world relations within the grand European project, itself the subject of the on-going Inter-Governmental Conference, to internal issues like how to allocate development portfolios within the Directorates General of the European Commission.

As the debate evolves, in think tanks, conferences and position papers ${ }^{5}$, it is possible to discern two alternative visions of the future of European development aid, no doubt with gradations in between. As visions go, these maximalist and minimalist versions of the future do not come entirely out of the blue ${ }^{6}$. They do, however, have brand new features, reflecting contemporary events like the debate on subsidiarity, the Final Act of GATT, the apparent tilt of EU priorities towards the Mediterranean, or the prospective enlargement of the EU to embrace countries in Eastern Europe. Figure 1 provides a schematic outline of the two competing visions, and in so doing helps to map the current debate about the future of European development aid.

At one extreme, the maximalist position aspires to the continuation of a contractual aid and trade partnership with the 70 countries of the ACP group, running in parallel and perhaps linked to programmes for other regional groupings, like Asia and the Mediterranean. The vision is of an aid programme enlarged and strengthened, so that aid channelled through the European Commission, so-called 'community action', comes to assume a larger share of total aid from European countries to the developing

\footnotetext{
2. Paper presented to a conference, "Europe and the Developing Countries", organised by the European Development Policy Study Group of the Development Studies Association of UK and Ireland, and held on 17 October 1996 at the Offices of the European Parliament in London. Helpful comments on an earlier draft were received from Chris Stevens and Sean Doyle. Responsibility, of course, is mine.

3. Source: DAC 1995. The figure is for 1994, up from \$US 1.4 bn in 1983/84. The figure for 1993 was \$US 3.9 bn.

4. Crawford (1996) and Lister (forthcoming) review the mid-term review process and discuss the increasing conditionality of EU aid. The financial settlement agreed for EDF 8, covering the period 1996-2000, was 12,967 Million ECU, to which should be added 1,658 MECU of resources from the European Investment Bank. This was no increase in real terms, despite the accession since EDF 7 of 3 new EU members (Randel and German (eds) 1996:209)

5. e.g. Stevens 1996, ECDPM 1996, Eurostep 1996.

6 . I have described them elsewhere (Maxwell 1993) as the 'Fattypuff' and Thinnifer' visions of EU aid.
} 
Figure 1

Maximalist and Minimalist positions for the evolution of European aid

\begin{tabular}{|l|l|l||}
\hline \hline & Maximalist position & Minimalist position \\
\hline \hline $\begin{array}{l}\text { Geographical } \\
\text { coverage }\end{array}$ & $\begin{array}{l}\text { Priority to 70 ACP countries, } \\
\text { parallel to programmes for other } \\
\text { regional blocs }\end{array}$ & $\begin{array}{l}\text { All developing countries } \\
\text { indiscriminately }\end{array}$ \\
\hline $\begin{array}{l}\text { Substantive } \\
\text { coverage }\end{array}$ & Aid and trade & Aid only \\
\hline $\begin{array}{l}\text { Contractuality } \\
\text { and partnership }\end{array}$ & Yes - renew Lomé & No - abandon Lomé \\
\hline Finance & $\begin{array}{l}\text { Maintain non-budgetary } \\
\text { European Development Fund }\end{array}$ & Budgetise all aid \\
\hline $\begin{array}{l}\text { Size of } \\
\text { programme }\end{array}$ & $\begin{array}{l}\text { Increasing - maximise } \\
\text { Commission 'acquis' }\end{array}$ & $\begin{array}{l}\text { Decreasing - 'renationalise' } \\
\text { wherever possible }\end{array}$ \\
\hline $\begin{array}{l}\text { Scope of } \\
\text { programme }\end{array}$ & $\begin{array}{l}\text { Broad - cover all aid } \\
\text { instruments, engage in policy } \\
\text { dialogue with recipient } \\
\text { countries }\end{array}$ & $\begin{array}{l}\text { Narrow - specialise in sector and } \\
\text { project aid, leave policy dialogue } \\
\text { to Bretton Woods Institutions and } \\
\text { humanitarian aid to the UN }\end{array}$ \\
\hline $\begin{array}{l}\text { Political } \\
\text { accountability }\end{array}$ & $\begin{array}{l}\text { More control by European } \\
\text { Parliament }\end{array}$ & $\begin{array}{l}\text { Maintain control by Member } \\
\text { States through Development } \\
\text { Council }\end{array}$ \\
\hline Administration & $\begin{array}{l}\text { Create European Development } \\
\text { Agency }\end{array}$ & $\begin{array}{l}\text { Simplify and streamline existing } \\
\text { bureaucracy }\end{array}$ \\
\hline \hline
\end{tabular}

world: bilateral aid, or 'national action' might, on this vision, eventually wither away. Growth would be accompanied by the development of greater policy expertise, so that the Commission would finally emerge as a heavyweight player in policy dialogue, acting as a counter-balance to the 'Washington consensus' of the Bretton Woods Institutions. It would require administrative reorganisation, and greater political accountability through the European parliament. In principle, this is certainly an attractive vision.

The minimalist position, by contrast, seeks to fetter the growth of EU aid and to 'renationalise' wherever possible, so that member state programmes predominate. It sees little value in preserving the contractual nature of the Lomé agreement, especially since trade preferences have been eroded by GATT; and it points to the inconsistency that many poor countries, especially those in South Asia, are not members of the ACP. On this reading, the minimalists would prefer a unified aid budget, covering all traditional countries, and run along traditional lines by a smaller and less dispersed aid 
administration in Brussels. They would maintain political control of the programme through the Development Council and its network of committees, rather than through the Parliament.

Adjudicating between these competing visions of the future - or negotiating a compromise between them - is partly a matter of political preference. However, policy analysis can also play a part, by illuminating the costs and benefits of different routes. Here, the key issue is quality. Is European aid in some sense 'better' than, or equivalent to, bilateral aid provided by member states - or, indeed, through the World Bank and the UN? If the answer to this question is positive, then there may be unequivocal benefits in moving towards the maximalist position. If, on the other hand, the answer is negative, then movement will be determined by whether the cost represented by lower quality is justified by political or other benefits.

Now, the question about aid quality is difficult to answer. It is difficult enough to establish whether or not aid has positive effects on growth, poverty reduction and social welfare, even in the aggregate, for all countries and all donors (White 1992, Mosley and Hudson 1995). It is much more difficult to do so for individual donors and individual countries (White 1995, Mosley and Hudson ibid.). The problem is made more complex when what is asked for is a comparison between one form of aid (community action) and another (national action). Despite the breadth and historical depth of the literature on aid, this is a question that is only beginning to be asked ${ }^{7}$.

In principle, there should of course be great advantages in European aid, as a slightly special form of multilateral aid. Comparing community action with national action (though not with UN or other 'pure' multilateral aid) there should be economies of scale, greater cost-effectiveness in procurement, clearer lines of political accountability, and simplification of administration. The EU also has a role, enshrined in the Maastricht Treaty, in the co-ordination of all aid from member states.

The study which this paper summarises does not provide answers to the comparative questions. However, as the first full-scale evaluation of European aid to a single country, it does shed light on the question 'Does European Aid Work?'; and in so doing, begin to shed light on the political debate between maximalists and minimalists.

7. DANIDA 1991, Cox et al 1995 
We need to advance in stages. Section 2 offers a brief exploration of what might be meant by the idea of aid 'working' or 'not working'. Section 3 summarises the findings of the Ethiopia study. And Section 4 explores the implications for the debate on European aid. In brief, the paper concludes that some aid, perhaps most, 'worked', but some did not - for reasons partly internal to Ethiopia and partly internal to the EU. The EU programme has improved markedly but could improve further: a seven point action programme is proposed to enable the EU to achieve an objective-driven strategy. A shift of resources from national action to community action would then be justified, capitalising on the economies of scale and the scope for more effective policy dialogue. A European Development Agency would also become an attractive idea.

\section{Measuring aid performance}

Writing originally in 1985, Cassen and associates (1994:6) defined aid effectiveness in development terms, deliberately excluding political and commercial considerations:

Does aid contribute macro-economically or otherwise to growth? Does it reach the poor? .... Does aid help or hinder an appropriate functioning of market forces?'

These questions have received much attention in the research-based academic literature (White ibid., Mosley and Hudson ibid.). The results are mixed. Acknowledging the difficulties of evaluation, Cassen and associates (ibid:7) reached 'at least a well-educated assessment' that 'most aid works'. Similarly, Mosley and Hudson (ibid:11), quoting World bank data, describe the 'positive direct effect of projects, as evidenced by the overwhelming positive rates of return reported at ex-post evaluation'. At the aggregate level, however, the indicators are less encouraging: summarising a variety of studies, Mosley and Hudson (ibid:11) conclude that the average impact of overseas aid (is) low or even neutral'. In the case of British aid to a sample of countries, 'significant influence on .... under 5 mortality is achieved more frequently than significant influence on growth' (ibid:6).

In the evaluation literature, mostly sponsored by aid agencies, aid performance has been approached more on a project by project basis, though sometimes at the sector level or by instrument (for example, food aid). At the same time, there has been less attention to overall impact in terms of the criteria set out by Cassen, and more to other aspects of performance. The inspiration here has been the logical framework, which 
sets out a structure for the relationship between inputs and overall development objectives, and also defines different levels of evaluation. These are reproduced in Figure 2, which distinguishes between efficiency, effectiveness and impact evaluation. The first is concerned with the outputs of a project (e.g. 'extension services provided'), the second with short term objectives or purposes (e.g. increase crop yields or agricultural output') and only the third with poverty reduction or growth (e.g. increase income or reduce poverty'). Thus, the term 'effectiveness', as used by Cassen, is here redefined as impact.

\section{Figure 2}

$\underline{\text { An Evaluation Model for Analysing Development Assistance Projects }}$

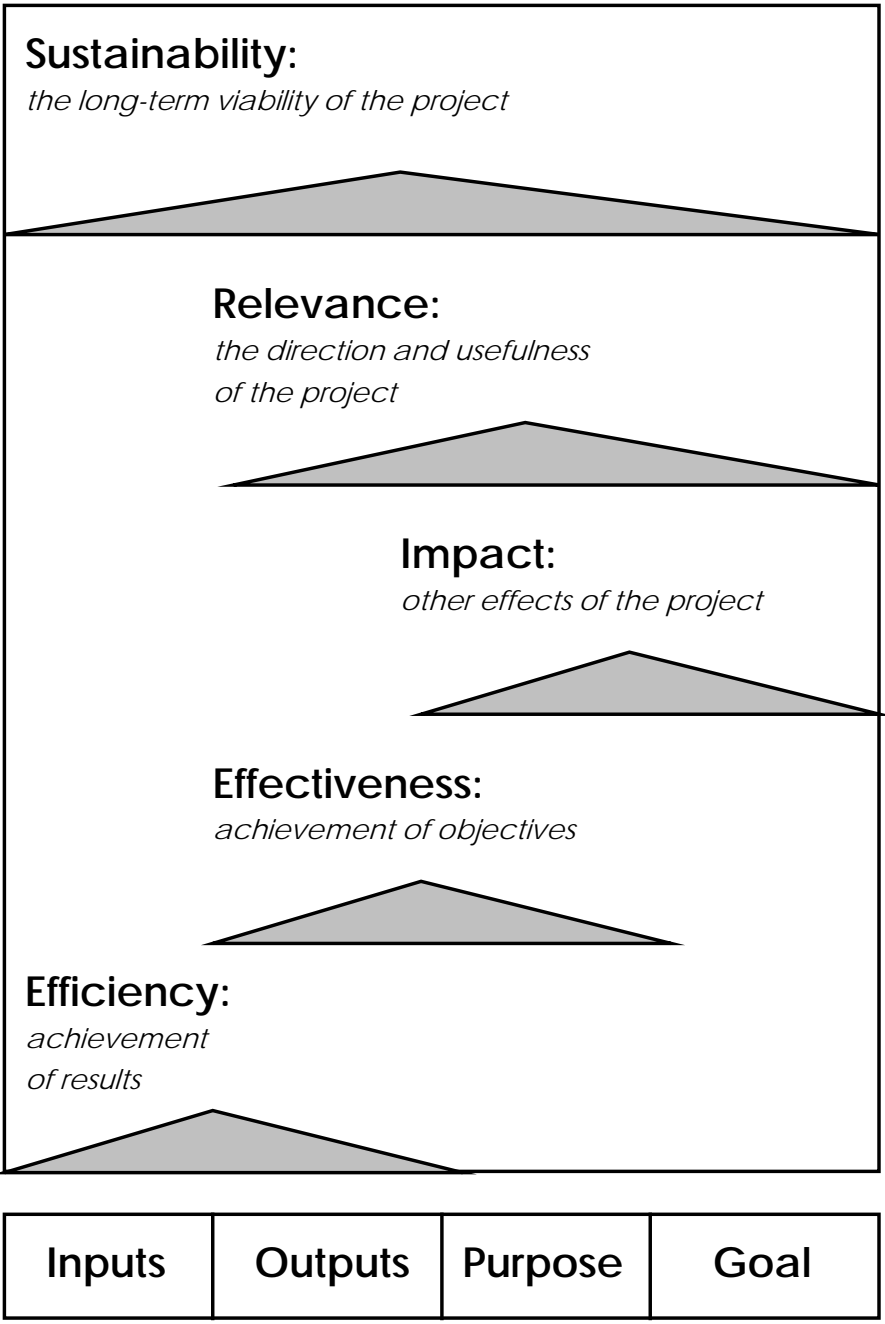

\section{Goal hierarchy}

Source: Norway, 1993: 23 
In practice, many evaluation studies do not consider impact, regarding the long term outcomes of projects as being somewhat remote from the inputs provided by aid, and subject to the influence of many external factors beyond the control of the project. Thus, the EU, for example, tends to concentrate on relevance, efficiency and effectiveness, defining them as in Box 1 below.

Three problems remain, even with the limits on evaluation set out in Box 1. First, 'aid' consists of many heterogeneous activities, some of which are much more difficult to evaluate than others. Standard evaluation methodology is derived from project-level social cost benefit analysis, in which direct effects can be identified and measured. This is not so easy in the case of programme aid (White and Toye (eds) forthcoming), technical co-operation (Berg 1993, Fukuda-Parr 1995) or other forms of aid which may have economy-wide benefits or substantial non-monetary benefits. Limiting evaluation to effectiveness and not impact simplifies the problem but does not entirely remove it.

\section{$\underline{\text { Box } 1}$}

\section{Relevance, effectiveness and efficiency}

Relevance: assesses the problems to be solved and the project objectives against their physical and policy 'environment', i.e. the main features of the sector and pertinent policies of the various actors.

Effectiveness: assesses the extent to which the project results have contributed towards the achievement of the project purpose or whether this can be expected to happen in the future on the basis of the current results of the project.

Efficiency: assesses whether the activities have been carried out efficiently in order to yield the project results. Have the means of the project been efficiently transformed through the project's activities into the various project results? Could the same or similar results have been achieved at lower cost?

Source: 'Evaluation Report Lay-out', EU Commission, Feb. 1995

The second problem is that of comparators. Against what standard is aid performance to be measured? Again, this is a relatively straightforward problem in cost-benefit analysis, where standard minimum rates of return can be defined, but is more difficult for non-project aid, and when it comes to defining effectiveness and efficiency. It is necessary for any evaluation to define its benchmarks in advance. 
Finally, the task of evaluation is not just to measure performance, but also to explain it. Explaining means addressing a new set of issues, which can be described as 'systemic': these refer to the attributes of the donor or the recipient, and are the areas in which recommendations need to be made.

\section{European Aid to Ethiopia, 1976-94}

(a) Introduction

As noted above, the Ethiopia evaluation was the first full-scale study of European aid to a single country. Field work was carried out in March 1995, and a seven volume report was published in June 1996 (IDS and IDR 1996). The task of the evaluation was to assess the relevance, effectiveness and efficiency of European aid. In addition, it was concerned with the management of the programme as a whole, both by the EU and by the Government of Ethiopia, and with the policies, procedures and administration of the EU aid system.

The methodological problems were those outlined in the previous section, namely the heterogeneity of the programme, the question of comparators and the need to identify underlying systemic issues. The methods used to overcome these problems included documentary analysis, key informant interviews, site visits, a limited amount of participatory rural appraisal, and five focus group discussions. The team also made use of the logical framework and of a specially designed evaluation scoring system (IDS and IDR ibid.: 2ff).

In terms of comparators, the team made reference to DAC best practice guidelines (OECD 1992) and to the EU's own policy documents (IDS and IDR ibid:117ff). The focus group discussions provided both a checklist of systemic issues and initial benchmarking of the EU against other donors (Maxwell 1996b). The checklist is reproduced in Figure 3 and provides a kind of best-practice charter for donors and recipients. 
Best practice criteria: a synthesis of focus group discussions

\begin{tabular}{|c|c|c|}
\hline How to be a good donor & "How to be a good recipient & How to be a good NGO \\
\hline 1. A clear development philosophy & $\begin{array}{l}\text { 1. Respect for human rights and } \\
\text { liberty of press }\end{array}$ & 1. Clear objectives \\
\hline 2. A wide range of instruments & 2. Internal peace and stability & $\begin{array}{l}\text { 2. Communication and co- } \\
\text { ordination with Government }\end{array}$ \\
\hline 3. A high grant element & 3. A commitment to development & $\begin{array}{l}\text { 3. Capacity-building and use of } \\
\text { local structures }\end{array}$ \\
\hline 4. Low tying of aid & $\begin{array}{l}\text { 4. Clear long and medium term } \\
\text { strategies }\end{array}$ & 4. Flexibility \\
\hline $\begin{array}{l}\text { 5. A jointly negotiated aid } \\
\text { framework }\end{array}$ & $\begin{array}{l}\text { 5. A commitment to open and } \\
\text { constructive policy dialogue at } \\
\text { macro and sector levels }\end{array}$ & 5. Community participation \\
\hline 6. A capacity for policy analysis & $\begin{array}{l}\text { 6. A good working relationship } \\
\text { with donors }\end{array}$ & 6. Advocacy \\
\hline 7. Constructive policy dialogue & $\begin{array}{l}\text { 7. The technical and administrative } \\
\text { capacity to identify, prepare and } \\
\text { appraise projects for donor } \\
\text { financing }\end{array}$ & 7. Attention to women's issues \\
\hline 8. A long term commitment & $\begin{array}{l}\text { 8. Clear lines of authority for } \\
\text { decentralised planning and } \\
\text { project implementation }\end{array}$ & $\begin{array}{l}\text { 8. Accountability - to the people, } \\
\text { government and donors }\end{array}$ \\
\hline $\begin{array}{l}\text { 9. A capacity for sector analysis } \\
\text { and planning }\end{array}$ & $\begin{array}{l}\text { 9. A commitment to beneficiary } \\
\text { participation }\end{array}$ & 9. Transparency \\
\hline 10. Cooperation with other donors & $\begin{array}{l}\text { 10. A commitment to meeting } \\
\text { staffing and local cost } \\
\text { provisions for projects }\end{array}$ & $\begin{array}{l}\text { 10. Low overheads and good } \\
\text { administration }\end{array}$ \\
\hline $\begin{array}{l}\text { 11. A commitment to genuine } \\
\text { recipient and stake-holder } \\
\text { participation in project selection } \\
\text { and design }\end{array}$ & 11. The absence of corruption & $\begin{array}{l}\text { 11. Compliance with government } \\
\text { guidelines }\end{array}$ \\
\hline $\begin{array}{l}\text { 12. Systematic and transparent } \\
\text { project appraisal and approval } \\
\text { procedures }\end{array}$ & $\begin{array}{l}\text { 12. Good administration and } \\
\text { accounting }\end{array}$ & $\begin{array}{l}\text { 12. Ability to link relief with } \\
\text { development by adopting an } \\
\text { integrated approach }\end{array}$ \\
\hline $\begin{array}{l}\text { 13. Decentralised decision-making } \\
\text { and management }\end{array}$ & $\begin{array}{l}\text { 13. Timely monitoring and } \\
\text { reporting }\end{array}$ & 13. Co-ordination between NGOs \\
\hline $\begin{array}{l}\text { 14. High technical capacity in field } \\
\text { offices and headquarters }\end{array}$ & $\begin{array}{l}\text { 14. A commitment to self-criticism } \\
\text { and learning }\end{array}$ & $\begin{array}{l}\text { 14. Use of local resources and } \\
\text { structures }\end{array}$ \\
\hline $\begin{array}{l}\text { 15. Continuity of project } \\
\text { management }\end{array}$ & & 15. Support to local NGOs \\
\hline $\begin{array}{l}\text { 16. Flexibility on the ground in } \\
\text { project operations }\end{array}$ & & $\begin{array}{l}\text { 16. Few expatriate staff and } \\
\text { employment opportunities for } \\
\text { nationals }\end{array}$ \\
\hline $\begin{array}{l}\text { 17. Quick, simple, open procedures } \\
\text { for financing and procurement }\end{array}$ & & $\begin{array}{l}\text { 17. Effective and efficient use of } \\
\text { resources }\end{array}$ \\
\hline $\begin{array}{l}\text { 18. Effective monitoring and } \\
\text { evaluation, leading to change }\end{array}$ & & $\begin{array}{l}\text { 18. Quality and timeliness of } \\
\text { reporting }\end{array}$ \\
\hline 19. A high level of accountability & & \\
\hline
\end{tabular}

Source: IDS and IDR 1996: Appendix VII 
(b) 'Hitting a moving target from a moving platform'

The EU committed over 2 billion ECU in 1990 prices in aid to Ethiopia between 1976 and 1994, equivalent to about \$ US 2.5 billion. The programme included both emergency relief and development aid. It drew on a wide variety of aid instruments available from the EU. And it touched almost every sector of the Ethiopian economy. Figure 4 illustrates the evolution of the programme over the period. It shows both substantial growth and a changing distribution. At the beginning of the period, in the Lomé I phase, most commitments fell under the National Indicative Programme, the main vehicle for disbursement under the European Development Fund. By Lomé III, the situation had changed as food aid (financed from the budget) became an important feature of aid to Ethiopia, and as Stabex also grew in importance. In Lomé IV, food aid remained substantial, Stabex grew even larger, and further diversification was brought about by the introduction of a new window for Structural Adjustment Support.

These changes illustrate the evolution of the EU aid programme over the period, particularly the diversification of instruments in Lomés III and IV ${ }^{8}$. There were other changes, too, particularly the increasing level of policy dialogue and policy conditionality in Lomés III and IV. Whereas the Lomé I and II periods were dominated by the idea of contractuality, in which the recipient countries took the lead in defining aid programmes, Lomés III and IV saw the gradual erosion of this principle, and its replacement with a more conventional approach. This tendency has been further reinforced in the Mid Term Review of Lomé IV.

At the same time, Ethiopia itself underwent major changes during the evaluation period. For most of that time, a socialist regime led by Mengistu Haile Mariam ruled the country, though engaged in a constantly escalating civil war which finally led to the overthrow of the regime in 1991 and the secession of Eritrea in 1993. The regime followed Stalinist policies until the late 1980s, characterised by pervasive state control of the economy, forced villagisation of the peasantry and compulsory resettlement programmes. In 1988, there was a partial liberalisation, followed in 1990 by a comprehensive move to a market economy. This process continued under the new government.

\footnotetext{
8. Apart from the introduction of Structural Adjustment Support, Lome IV also saw the innovation of programme aid within the National Indicative Programme, in the form of Sectoral and General Import Programmes.
} 
Aid Flow to Ethiopia, 1976-1993

Average Annual Commitments by Lomé Agreement (at constant 1990 ECU)

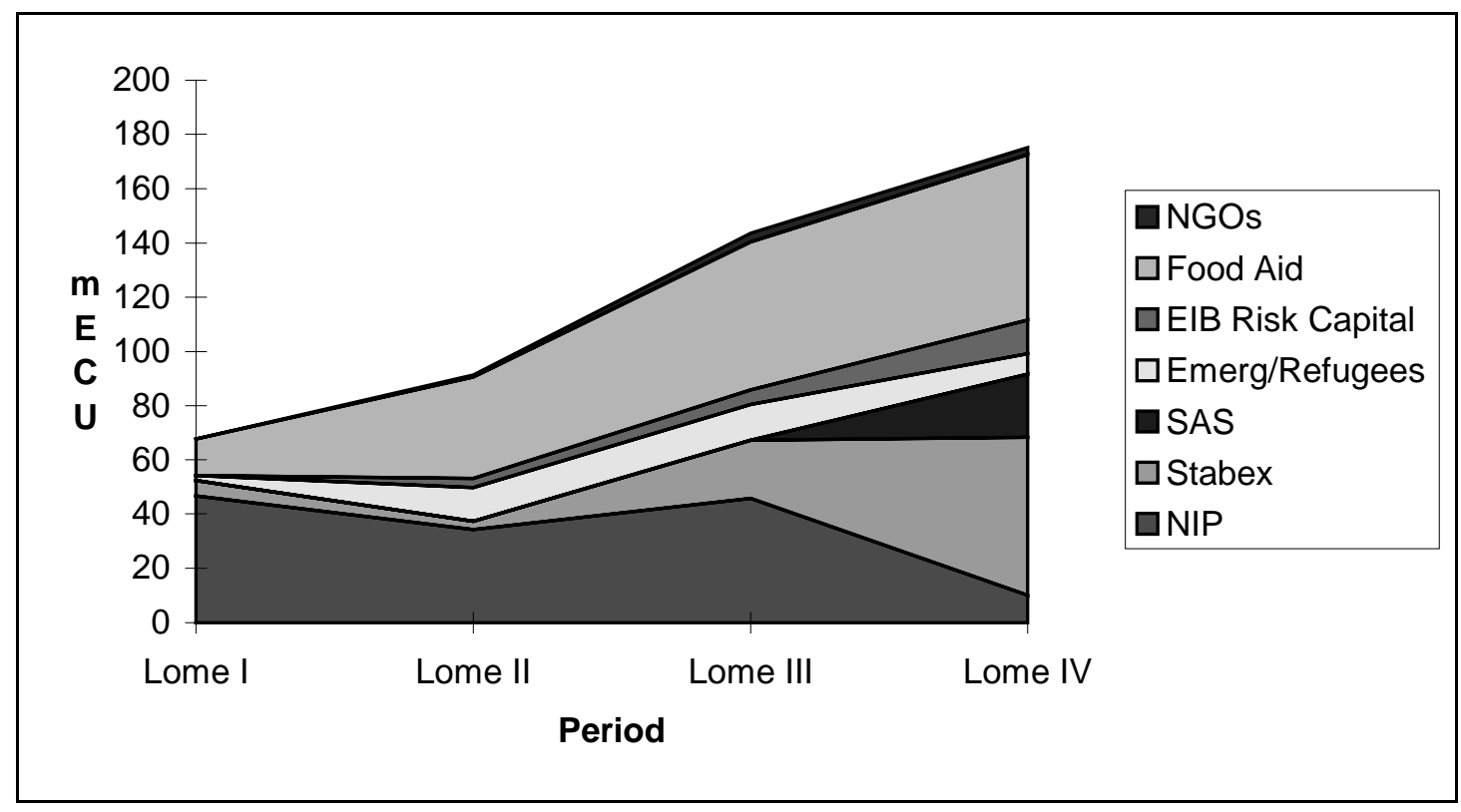

NB: Lomé IV excludes Eritrea

Changes of this magnitude on both the donor and recipient sides muddy the waters of evaluation. More importantly, they greatly complicated the planning and management of the aid relationship. The National Indicative Programme for Lomé IV, for example, due just at the time the Mengistu regime was overthrown, had effectively to be negotiated three times - and continuing negotiations with the new Government meant that four years into the Lomé period, at the end of 1994, only 20 per cent of the resources earmarked had been committed. In any case, it is important not to judge the programme by standards that were inappropriate at the time, and to take into account the problem of 'hitting a moving target from a moving platform'.

(c) Sectoral perspectives

Figure 5 illustrates the sectoral distribution of EU aid expenditure over the evaluation period. On the development side, infrastructure was the dominant sector in Lomés I and II, agriculture took over in Lomé III, and programme aid (including Stabex) has been dominant in Lomé IV. These sectoral priorities reflected changing thinking in successive Lomé agreements. Food aid grew rapidly, as can be seen, and was mostly destined for emergency purposes, although a proportion was used for development projects, and, latterly, for sale to support the market and generate counterpart funds. 


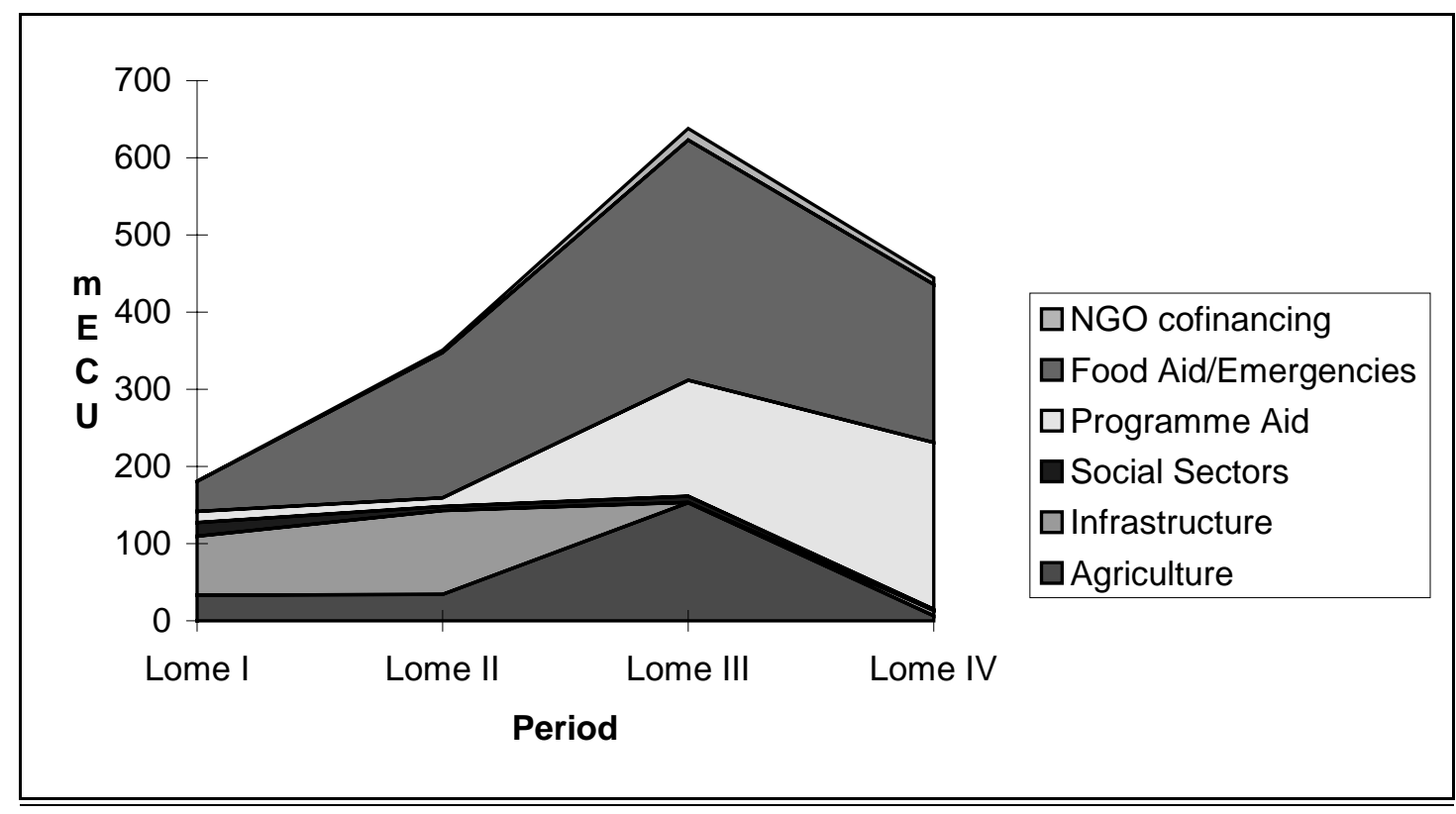

NB: Lomé IV excludes Eritrea

Within these broad parameters, the EU supported a wide variety of activities: large agricultural projects, like the Shoa Peasant Area Development Project (PADEP) and the Coffee Improvement Programme; major infrastructure, like water supply for Addis Ababa or the power line for Dessie; hospitals and roads, fertiliser imports and budget support, NGO co-financing projects; and, of course, a very large volume of food aid.

The evaluation 'story' told by this heterogeneous package is inevitably complex. The activities cover different kinds of aid, trying to achieve different things, in different places, and at different moments in the evolution of European aid policy and Ethiopian political economy. Much good work was accomplished, and very many lives were saved by emergency relief.

A number of themes run through the evaluation reports: the enormous difficulties of 'doing business' in Mengistu's Ethiopia; the negative impact of an unfavourable policy environment; the challenges posed by repeated shocks, whether climatic, political or economic; 'learning by doing' and gradual improvement in the quality of the EU programme; but nevertheless a mixed record of success and failure, with scope for further improvement. 
In general, it was evident that some activities out-performed others. Thus, in infrastructure, water and energy, the large engineering projects, like the Amarti Diversion project or the Addis Ababa water supply project, were more successful than the geographically scattered and socially complex projects, like rural water supply. In the agriculture field, also, the technology-driven projects, like Amibara irrigation and Central Shoa PADEP, seemed to out-perform projects in more difficult physical and social environments, like soil conservation projects. In the programme aid sector, the agricultural Sectoral Import Programme, another fairly straightforward project, scored more highly than more complex alternatives, notably Stabex.

It was difficult to reach generalisations about comparative sectoral performance. However, it was notable that the food aid and agriculture/rural development evaluations were generally less favourable than those of the other sectors.

These findings, it has to be said, are not unfamiliar in the aid evaluation literature: a mixed pattern of success and failure, the difficulty of managing socially-complex poverty reduction projects, the dominant importance of the recipient country's domestic policy environment, all these are themes common to most analysis of aid (see e.g. Cassen and associates ibid.). The interesting evaluation question is how far the pattern of success and failure can be explained by the attributes of the donor agency and by the quality of the aid relationship it enjoyed. It is in examining this question that we come closer to the underlying quality questions about European aid.

(d) Thematic issues ${ }^{9}$

The analysis of thematic issues in the evaluation report is carried out under the headings of 'relevance', 'effectiveness' and 'efficiency'. The following is a brief and partial summary.

\section{Relevance: Policy, Planning and Programming}

In terms of overall relevance, the EU aid programme in Ethiopia certainly addressed issues of fundamental importance to one of the poorest countries of the world. There can be no criticism of the programme for concentrating on rural infrastructure and rural development, for providing a large amount of food aid, especially during and

\footnotetext{
9. The text of this section is an abridged and edited version of the relevant section of the summary of IDS and IDR 1996.
} 
after the great famine of $1984 / 85$, or for supporting economic liberalisation and structural adjustment through the Emergency Recovery and Reconstruction Programme after 1991. The large infrastructure projects in energy and water supply also appear to have met a genuine need.

The issues that arise are more subtle: first, the political question of providing aid to a totalitarian regime in the 1970s and 1980s; secondly, questions about critical mass and integration of instruments; and, thirdly, an issue about the capacity to engage in the policy analysis and policy dialogue required to mount successful projects.

The political issue was not trivial for a country with a very poor human rights record and the status of a pariah state among most other western donors. EU development aid unfortunately provided some moral comfort to the regime and may have supported the war indirectly. Under Lomés I and II, the EU formally had no room for manoeuvre and was bound by the contractuality provisions of the Convention ${ }^{10}$. Under Lomé III, when conditions changed, the EU engaged in a major programme of policy dialogue. It is ironic that the EU finally 'geared up' to handle difficult regimes, just at the time when Ethiopia was moving rapidly in the EU's direction.

On critical mass and integration of instruments, by far the biggest problem was the lack of linkage between food aid and other instruments, caused by different sources of funding and different planning procedures. As a result, food and financial aid were largely directed to different parts of the country and opportunities for complementarity, including in policy dialogue, were missed. There were similar problems with other budget lines (of which there are more than thirty altogether, though not all applicable to Ethiopia).

The multiplicity of aid instruments and the complexity of the EU programme in Ethiopia suggest that a single country programme is needed. Yet the planning cycle for the five-yearly National Indicative Programmes has not met the need, because a large part of aid has been outside the NIP. A more general country strategy has, however, been prepared for the Lomé IV bis period, covering 1996-2000.

As country programmes are prepared, and as these are then turned into sectoral programmes and finally into projects, a capacity to carry out policy dialogue is essential. The EU was weak on policy dialogue until Lomé III, for reasons already

\footnotetext{
10. The extent of the 'room for manoeuvre' is debateable, however. In the case of Uganda under Amin, Lister (1988) has argued that the EU went through the motions of negotiating and approving aid programmes, but then delayed actual disbursement until the human rights position had improved.
} 
discussed. It took important initiatives under Lomé III and made a positive contribution, along with other donors and reformers within the Government. There were other success stories later, for example the leadership role of the EU in negotiating a new approach to the management of counterpart funds. Nevertheless, performance on policy dialogue was uneven. The EU was repeatedly described to the evaluation team as 'punching below its weight'.

\section{Effectiveness and Sustainability}

On effectiveness and sustainability, the main issue which arose was the unfavourable policy environment during much of the period reviewed. However, there were also some problems with project design, and with the lack of continuity of support to some projects.

Many projects would have seemed much more successful in retrospect had the policy environment been better. The policy of the Mengistu Government had some positive features, including the land reform of 1975 and the commitment to literacy campaigns in the late 1970s and early 1980s. However, the overall balance was negative: in terms of market control and pricing, problems of state-sponsored institutions, and poor policy, including forced villagisation and resettlement. The war also had an important negative effect: apart from the loss of life and the cost, a great deal of infrastructure was damaged or destroyed. Several EU-supported institutions were looted during the final days of the Mengistu regime.

In terms of project design, there was a general problem with over-centralisation and over-standardisation, reflecting a bias of the Ethiopian Government that the EU should perhaps have done more to challenge. More generally, EU projects would have benefited from the preparation of stronger appraisal reports, and from earlier adoption of the logical framework as a planning tool. The standards of project cycle management appeared to be higher for EDF-funded projects than for projects funded by EU budget lines.

Support to particular projects was sometimes insufficient. The discontinuities between Lomés may help to account for this. At the same time, field-level initiatives were hampered by long chains of decision-making back to Brussels. 


\section{Efficiency: Management, Supervision and Reporting}

Questions of management, supervision and reporting featured prominently in key informant interviews and focus group discussions. In the focus groups, for example, speed of decision-making, efficiency of administration and project management were all cited as areas where the EU compared unfavourably with other donors. In many cases, routine project management was favourably evaluated, presumably as a result of the joint effort of Ethiopian Government staff and EU contractors. However, problems were cited on the Government side, and also, very forcefully, on the side of the EU. The main problem areas were delegation of authority, staffing, procedures, and reporting.

The issue of decentralisation is best exemplified by the lack of delegated authority to approve projects at the country level, a situation which contrasts markedly with other donors. It has costs in terms of the long delays in the system: up to a year to approve an NGO project or a Framework of Mutual Obligations for Stabex, and long delays in procurement. The problem is compounded by overly complex procedures. It seemed that the word 'Delegation' was a misnomer for EU field offices.

The problem of under-staffing was manifest in the lack of junior professional and support staff to assist Delegation Advisers and the desk officer in Brussels. USAID, for example, had 25 local professional staff in Addis Ababa (excluding administration and public relations), the EU had none. This was particularly surprising, as one EU international staff member cost at least twenty times as much as a similarly wellqualified Ethiopian recruited locally.

Food aid provided an extreme case of lack of professional input at the field level. In 1994, there was one logistics specialist, with little policy role or local administrative support, to monitor a programme costing over 30 per cent of total EU commitments to Ethiopia. Partly as a result, the Delegate and other officials, with other responsibilities, were drawn into the food aid programme. A new unit had, however, just been established in the Delegation, adding two additional posts.

The staffing problem had a number of knock-on costs. One was the heavy reliance on consultants, which has adverse consequences for continuity. For example, the Coffee Improvement Project had been subject to at least six different reviews, each undertaken by a different consultant organisation. 
Finally, on monitoring and evaluation, the sectoral reports identified a need for more evaluation of project effects and impact, perhaps through the medium of regular end of project completion reports. Statistical reporting had been a problem in the past, and although matters seemed to be improving, standards for most of the period had been unacceptable. The absence of a single, annual report on all aid from the EU to developing countries was a major omission.

\section{(e) Conclusions}

Drawing the analysis together, the study of European aid to Ethiopia shows both strengths and weaknesses. An overriding impression, however, confirmed in focus group discussions, was of an aid programme that was bigger than the capacity to manage it, a problem of not cutting the coat according to the cloth. As one commentator put it, 'the EU's eyes are bigger than its stomach' (IDS and IDR 1996: 107).

There are seven main ways, however, in which the programme can be improved. These are listed in Figure 6. Some of these are Ethiopia-specific, but mostly they refer to the policy, planning, procedures, staffing and management of the European aid system as a whole. The report contains some 90 separate recommendations on these matters. Budget lines to be eliminated or amalgamated. A policy manual to be prepared. A procedure for unified country strategies to be introduced. Delegations to have budgets under their own control for policy analysis and programme development. The ceiling for local approval of projects to be raised from the present level of ECU 60,000. A task force to be set up to review reporting procedures. Local professionals to be appointed to Delegations. And so on.

In practical terms, the evaluation concluded that the EU faced a clear choice in Ethiopia between two different strategies. One was to opt for an 'objective-driven strategy' and to tackle the problems listed in Figure 6. The other was to 'cut the coat according to the cloth'. This would mean maximising the return to the scarce resource, which in the opinion of the evaluation team was 'professional staff time to plan, manage, monitor and evaluate an aid programme characterised by unusually great diversity and complexity' IDS and IDR ibid.: 111). The strategy would involve maximising disbursement per unit of professional input, which would bias the programme to large-scale resource transfers like programme aid and large infrastructure projects, at the expense of impact on poverty, food security and other EU objectives. Clearly, an objective-driven strategy was preferable. 
Figure 6

\section{Improving the EU aid programme in Ethiopia: 7 key issues}

1. Simplifying and focusing the range of aid instruments.

2. Strengthening strategic planning at the country level, esp. with respect to integration of instruments.

3. Improving macro-economic and sectoral policy analysis and policy dialogue (with Government and other partners).

4. Reinforcing the project cycle, leading to better project preparation and supervision.

5. Decentralising and simplifying aid administration.

6. Improving standards of reporting.

7. Better deployment of human resources, especially support for Professional staff.

\section{Conclusion}

We started with the question 'Does European Aid Work?', and with the supposition that there might be particular advantages in terms of economies of scale or political conditionality that would justify an enlargement of EU aid at the expense of national action. The Ethiopia study allows two sorts of answers to the over-arching question about the effects of aid.

First, the study shows that some, perhaps most, European aid has 'worked', in the sense of achieving its short-term objectives; but, equally, that some has not. This answer needs to be understood as a historical judgement on a period during which the programme has evolved substantially and in which Ethiopia presented peculiar problems and difficulties. There is certainly evidence that the quality of the programme has improved over time.

Secondly, however, further improvement is possible, and needed if the EU is to reach the target of an objective-driven strategy. The results of the evaluation and the comments of the focus group discussions held in Addis Ababa coincide in the finding that the capacity of the EU to implement an aid programme falls some way below its capacity to agree an over-arching aid framework and establish appropriate aid instruments. In the focus group discussions, the EU was praised for the overall quality 
of the aid framework provided by the Lomé Convention, for the range of aid instruments at its disposal, and for providing aid in grant form. However, it was seen to compare poorly with some other donors in policy analysis, project preparation, delegation of authority to the field, speed and flexibility of procedures, and staffing levels. The seven point programme in Figure 6 reflects these concerns.

Seen in this light, the question of whether EU aid is 'better' or 'worse' than bilateral programmes is the wrong question. Some of it is undoubtedly better; some undoubtedly worse. More accurately, the best of EU aid is certainly better than the worst of bilateral aid; and the best of bilateral aid is certainly better than the worst of EU aid. For example, sacrificing commercially-motivated aid like the infamous Pergau dam in favour of a sound project like Ethiopia's Amarti river diversion would improve overall quality; but sacrificing a good bilateral rural development project to fund, say, more EU dairy aid, would reduce it.

Thus, the question about transferring resources from national programmes to the EU is actually much more interesting than simply one about transferring resources willynilly from one budget to another. Instead, the question needs to be framed in terms of what will be cut on one side, and what will be increased on the other. This discussion has yet to take place.

At the same time, both maximalists and minimalists have an interest in improving the quality of EU aid, along the lines set out in Figure 6. Some of the changes are already underway, as indicated above. However, the package is not complete. EU aid could be much better (even better) than it already is. I have argued elsewhere (Maxwell 1996a) that the underlying problems are political in nature, reflecting sins of omission and sins of commission in the political arena. For example, the multiplicity of budget lines, which so complicates the administration of EU aid, probably results from attempts at ear-marking by the European parliament. Similarly, the chronic understaffing of the EU aid administration partly reflects expenditure limits imposed by the member states (only partly, because many problems could be solved by appointing more professional, local staff within existing budgets). Perhaps the current evaluation of aid to the ACP, expected to report by early 1997, will offer a vehicle for the resolution of these problems. Or is a political initiative is needed, like a European Enquiry into EU aid?

Finally, does any of this help us to adjudicate between maximalists and minimalists? On some issues, the Ethiopia study is silent. For example, it cannot be used to 
illuminate the question of whether aid to Asia, say, or the Mediterranean, would be better framed in a Lomé-type framework. Nor did the Ethiopia study deal with trade. On other issues, however, it is possible to extrapolate - allowing, of course, for the particularities of the Ethiopian case.

On contractuality and partnership, the study gives comfort if anything to the minimalists. It eloquently supports the case against the automaticity of aid, showing how much the quality of the programme improved when automaticity began to be eroded in Lomé III. In the focus group discussions, recipients said they valued an explicit and negotiated aid framework and a guaranteed flow of funds. On the first, there is no real reason why an aid framework, setting out priorities and defining policies, should be couched in the form of an international treaty; other donors have frameworks without treaties. On the other hand, this is not the same as a "negotiated" framework, and many observers see value in the apparatus of ACP institutions that has been created to negotiate successive Lomé agreements - even though the scope for real negotiation has been progressively eroded. The political case for the continuation of Lomé institutions may be stronger than the instrumental case. The real benefits need to be debated, however. On the flow of funds question, a guaranteed flow whatever the state of domestic economic policy or the human rights position of the recipient country is clearly, and rightly these days, too much to hope for.

On finance, the Ethiopia study provides strong support for a unified budgeting system, with one set of procedures and one mechanism for accountability. It does not particularly favour the EDF over the budget or vice-versa, though it does note that historically EDF proposals and reporting standards were generally higher than for budget line items (especially food aid). This may comfort the maximalists.

On the scope of the programme, the study provides evidence that there are potential economies of scale in bringing European aid together under a single umbrella with a range of possible instruments, not least in the scope for policy dialogue. It was notable that many donors, including some of the heavy-weight players in Ethiopia, were anxious that the EU should not continue to punch below its weight, and that it should play a better informed and more active part in policy dialogue. However, the EU's potential has not always been fulfilled, and the study suggests that the Commission needs both more resources and a greater focus on country-level planning if it is to be realised. Comfort here again for the maximalists. 
On political accountability, the study is neutral, but identifies serious problems in the sphere of reporting, both at country level, and more generally. This suggests that improving the structures of accountability may be less important than improving the content. Whoever controls European aid, however, the Ethiopian study also provides strong support for less intervention from outside, whether in the form of the European parliament insisting on new budget lines, or the Member States insisting on project approval in a network of Development Council committees. Decentralisation and greater autonomy of decision-making should be the watchwords of any reform of governance of European aid.

Last but not least, administration emerges from the Ethiopia study as the Achilles heel of European aid. If this is true for an aid programme in Ethiopia serviced largely by one Directorate General, how much more true must it be for the multiplicity of structures serving the totality of developing countries. A single, semi-autonomous European Development Agency begins to look very attractive. 
Bibliography

Berg, E., 1993, Rethinking Technical Assistance and Capacity Building in Africa, New York: UNDP

Cassen, R., and Associates, 1994, Does Aid Work?', 2nd. edition, Oxford University Press

Cox, A., J. Healey and A. Koning, 1995, European Union Aid Agencies Comparative Management and Effectiveness, 2 vols., ODI/ECDPM, London and Maastricht

Crawford, G., 1996, 'Whither Lomé? The Mid-Term Review and the Decline of Partnership', Paper presented at the European Development Policy Study Group, Development Studies Association Conference, University of Reading, 18-20 September, 1996

DAC, 1995, Development Cooperation: Efforts and Policies of the Members of the Development Assistance Committee, 1995 Report, OECD, Paris

DANIDA, 1991, Effectiveness of Multilateral Agencies at Country Level: European Communities in Kenya and Sudan, prepared for DANIDA by COWIconsult

European Commission, 1996, Green Paper on Relations Between the European Union and the ACP: Challenges and Options for a New Relationship, European Commission, Brussels

ECDPM, 1996, 'Beyond Lomé IV: Exploring Options for Future ACP-EU Cooperation', Policy Management Report, No. 6, European Centre for Development Policy Management, Maastricht, October

EUROSTEP, 1996, Partnership 2000: A Eurostep Approach, Mimeo, Eurostep, Brussels, September

Fukuda-Parr, S., 1995, 'Redefining Technical Cooperation: Challenge for the UN or Let's Dump the Technical Cooperation Mandate' in IDS Bulletin, 26:4, October

IDS and IDR, 1996, An Evaluation of Development Cooperation Between the European Union and Ethiopia, 1976-1994, 7 vols., Institute of Development Studies, University of Sussex, and Institute of Development Research, University of Addis Ababa, June

Lister, M.R. (forthcoming), Europe and the South, Routledge 
Lister, R., 1988, The European Community and the Developing World, Avebury: Aldershot

Maxwell, S., 'Fattypuffs and Thinifers in the Debate about European Aid', in House of Lords, Select Committee on the European Communities, 1993, EC Development Aid, HL Paper 86, HMSO, May

Maxwell, S., 1996a, The reform of European Aid: A Proposal', mimeo, July

Maxwell, S., 1996b, The Use of Focus Groups to Identify Systemic Issues in Country Programme Evaluations: The Case of EC/EU Aid to Ethiopia', Paper presented to the Annual Conference of the Development Studies Association, Reading, 18-20 September, 1996

Mosley, P., and J. Hudson, 1995, 'Aid Effectiveness: A Study of the Effectiveness of Overseas Aid in the Main Countries Receiving ODA Assistance', mimeo, November

Norway, 1993, Evaluation of Development Assistance: Handbook for Evaluators and Managers, Royal Ministry of Foreign Affairs, Norway

OECD, 1991, Principles for Evaluation of Development Assistance, Organisation for Economic Cooperation and Development, Paris

Overseas Development Institute, 1995, 'EU Aid Post-Maastricht: Fifteen into One?', Briefing Paper, ODI, London, April

Price Waterhouse, 1992, Study of the Causes of Delay in the Implementation of Financial and Technical Cooperation, Report to the European Commission, Brussels

Randel, J., and T. German (eds), 1996, The Reality of Aid: An Independent Review of International Aid, ICVA and Eurostep, Earthscan: London

Stevens, C., 1996, 'Globalisation and Differentiation in EU Development Policy', Paper to Partnership 2000 Reflection Group, mimeo, Institute of Development Studies, University of Sussex

White, H, and J. Toye (eds), 1996, 'Evaluating Programme Aid', IDS Bulletin, 27:4, October

White, H., 1992, The Macroeconomic Impact of Development Aid: A Critical Survey', in Journal of Development Studies, Vol. 28

White, H., 1995, 'How Much Aid is Used for Poverty Reduction' in IDS Bulletin, 27:1, January 